\title{
Tradisi Ritual Kematian Islam Kejawen Ditinjau Dari Sosiologi Hukum Islam
}

\section{Nurul Mahmudah,}

Institute Agama Islam Negeri Jurai Siwo Metro

mafazasyafira@gmail.com

\author{
Abdur Rahman Adi Saputera \\ Institut Agama Islam Negeri Sultan Amai Gorontalo \\ adisaputrabd@gmail.com
}

Abstract: The arrival of Islam on Java gave a new color to the ceremonies in the Javanese tradition, including the death ceremony. Although it is now "Islamic", some Muslims still reject the tahlilan tradition. They consider him to be an unclean bid'ah. Because the tahlilan tradition has never been disyariatkat by Allah and has never been done by the prophet and his friend. While those who support the tahlilan tradition assume that this tradition is tantamount to the teachings of reciting the holy verses of the Koran for the dead, which is an Islamic recommendation. In addition, the tahlilan tradition also contains social concerns. This paper aims to examine how the ritual tradition of death in Kejawen Islam. The researcher used a historical analysis approach. The ritual tradition of the death of Islam Kejawen is the reading of prayer for the deceased whose implementation is adapted to the Javanese cultural heritage before the arrival of Islam. the essence of this ritual is to foster the spirit of da'wah, build togetherness, draw closer to Allah through dzikir, prayer, 
and recitation of the Qur'an. So if this is the meaning of tahlilan, even though the practice is not in the Shari'a and the Sunnah, according to the researchers it is good to do it.

\begin{abstract}
Abstrak: $\quad$ Masuknya Islam ke Jawa memberikan warna baru pada upacaraupacara dalam tradisi Jawa, termasuk upacara kematian. Walaupun kini sudah "Islami", akan tetapi sebagian umat Islam masih menolak tradisi tahlilan. Mereka menganggapnya sebagai bid'ah yang haram. Sebab tradisi tahlilan tidak pernah disyariatkat oleh Allah dan tidak pernah dilakukan oleh nabi dan sahabatnya. Sementara kalangan yang mendukung tradisi tahlilan beranggapan, bahwa tradisi ini sama saja dengan ajaran membacakan ayat suci al-Qur'an untuk orang mati, dimana hal itu merupakan anjuran Islam. Selain itu, tradisi tahlilan juga mengandung kepedulian sosial. Tulisan ini bertujuan meneliti bagaimana tradisi ritual kematian pada Islam Kejawen. Peneliti menggunakan pendekatan analisis historis. Tradisi ritual kematian pasa Islam kejawen adalah pembacaan do'a untuk yang meninggal dunia yang pelaksanaannya disesuaikan dengan warisan budaya Jawa sebelum datangnya Islam. esensi ritual ini adalah untuk menumbuhkan semangat dakwah, membangun kebersamaan, mendekatkan diri kepada Allah melalui dzikir, do'a, dan bacaan al-Qur'an. Sehingga jika demikian makna tahlilan, meskipun praktiknya tidak ada dalam syariat dan sunnah maka menurut hemat peneliti baik dilakukan.
\end{abstract}

Kata kunci: Ritual kematian, Islam Kejawen.

\title{
A. Pendahuluan
}

Secara sosiologi, Agama Islam mengalami perubahan terhadap ritual yang dilakukan masyarakat karena adanya pengaruh budaya Indonesia. Jika dalam suatu masyarakat memiliki budaya lokal yang khas maka secara tidak langsung agama yang dianut oleh masyarakat setempat akan selalu dikaitkan dengan berbagai ritual yang dilakuka. ${ }^{1}$ Agama, budaya dan masyarakat akan selalu berjalan beriringan sesuai dengan apa yang di interpretasikan masyarakat bahwa budaya dan agama adalah satu kesatuan yang tidak akan pernah terpisahkan.

Di Indonesia, Khususnya daerah Jawa terdapat kelompok Kejawen. Kejawen adalah sebuah corak kepercayaan yang terutama

${ }^{1}$ Sudirman Tebba, Sosiologi Hukum Islam (Yogyakarta: UII Press, 2003), ix. 
yang dianut di pulau Jawa dan suku bangsa lainnya yang menetap di Jawa. Kejawen sebenarnya adalah nama sebuah kelompok kepercayaan yang mirip satu sama lain dan bukan sebuah agama yang terorganisir seperti agama Islam atau agama Kristen. ${ }^{2}$ Ciri khas dari Kejawen adalah adanya perpaduan antara animisme, agama Hindu dan agama Budha. Tepatnya adalah sebuah kepercayaan sinkretisme.

Masyarakat kejawen khususnya Islam kejawen terdapat tradisi ritual yang sederhana, formal, jauh dari keramaian serta apa adanya. Ritual adalah suatu teknik atau cara yang membuat suatu adat kebiasaan menjadi suci (sanctify the custom). Ritual menciptakan dan memelihara mitos, adat sosial, dan agama. Ritual bisa bersifat pribadi ataupun berkelompok. Wujudnya bisa berupa tarian, drama, doa, dan sebagainya. ${ }^{3}$ Secara keseluruhan akrab dangan sebutan "Slametan". Slametan berasal dari kata slamet (Arab: salamah) yang berarti selamat, bahagia, sentausa. Selamat dapat dimaknai sebagai keadaan lepas dari insiden-insiden yang tidak dikehendaki. Sementara itu, menurut Clifford Geertz slametan adalah suatu bentuk acara syukuran dengan mengundang beberapa kerabat atau tetangga. Secara tradisional acara syukuran dimulai dengan doa bersama, dengan duduk bersila di atas tikar, melingkari nasi tumpeng dengan lauk pauk. ${ }^{5}$

Sebelum Islam masuk ke Indonesia, slametan identik dengan sesajen yang di persembahkan untuk roh-roh halus. Setelah Islam masuk ke bumi Nusantara, para penyebar Islam berupaya menyisipkan nilai-nilai Islam di dalamnya. Mereka berusaha merubah tradisi slametan bukan lagi sebagai persembahan untuk makhluk halus, melainkan sebagai sedekah yang tidak hanya merekatkan hubungan antara masyarakat, akan tetapi juga melatih kepedulian sosial. ${ }^{6}$

Walaupun kini sudah "Islami", akan tetapi sebagian umat Islam masih menolak tradisi tahlillan. Mereka menganggapnya sebagai bid'ah yang haram. Sebab tradisi tahlilan tidak pernah disyariatkat oleh

${ }^{2}$ Ahmad khalil, Islam Jawa, (Sufisme dalam etika dan Tradisi Jawa) (Malang: UIN Malang Press, 2008), 277.

${ }^{3}$ Salah satu contoh prosesi ritual dalam tradisi Jawa nampak pada Ritual Pengesahan Warga Baru Persaudaraan Setia Hati terate. Lihat Fauzan, "Akulturasi Islam dan Budaya Jawa: Kajian Pada Ritual 'Pengesahan' Warga Baru Persaudaraan Setia Hati Terate,” Kalam Vol. 6, no. 1 (2012): 105-24.

${ }^{4}$ Khalil, Islam Jawa...h. 277.

${ }^{5}$ Ibid., 278.

${ }^{6}$ Koentjaraningrat, Kebudayaan Jawa (Jakarta: Balai Pustaka, 1984), 125. 
Allah dan tidak pernah dilakukan oleh Nabi Muhammad SAW dan sahabatnya. Tradisi ini merupakan transfer pahala dari orang yang masih hidup kepada yang sudah mati, dan itu bertentangan dengan ajaran Islam. Tradisi ini akan membuat orang mudah berbuat dosa, karena dia berkeyakinan bahwa dosanya bisa ditebus dengan tahlilan dan dzikir fida'. Hal itu mudah dilakukan oleh orang-orang kaya. Tradisi ini merupakan tindak pemborosan, karena memberikan sedekah kepada orang-orang yang tidak membutuhkan (bukan fakir miskin).

Pendapat ini seirama dengan pandangan Ibnu Hajar al-Haitami. Dalam al-Fatawi al-Kubra, Ibnu Hajar berpendapat bahwa peringatan hari ketiga, ketujuh, dan lain-lain yang telah membudaya di masyarakat, termasuk bid'ah madzmumah (bid'ah tercela), akan tetapi tidak diharamkan, selama bukan untuk meratapi kematian si mayit. ${ }^{7}$

Sementara kalangan yang mendukung tradisi tahlilan menilai, bahwa tradisi ini sama saja dengan ajaran membacakan ayat suci alQur'an untuk orang mati, dimana hal itu merupakan anjuran Islam. Selain itu, tradisi tahlilan juga mengandung sisi positif, antara lain: Menumbuhkan semangat dakwah, mengingatkan kita bahwa akhir kehidupan dan menanamkan jiwa kepedulian sosial terhadap sesama. ${ }^{8}$

Slametan dilakukan untuk merayakan hampir semua kejadian, termasuk kelahiran, kematian, pernikahan, pindah rumah, dan sebagainya. ${ }^{9}$ Dengan pendekatan analisis historis, Tulisan ini bertujuan meneliti bagaimana tradisi ritual kematian pada Islam Kejawen.

\section{B. Sosiologi Hukum Islam}

Sosiologi hukum menurut Soejono Soekanto ${ }^{10}$ adalah cabang ilmu pengetahuan yang secara analitis dan empiris mempelajari hubungan timbal balik antara hukum dengan gejala sosial lainnya. Sosiologi Hukum merupakan ilmu yang membahas pengaruh timbal balik antara perubahan hukum dan masyarakat. Perubahan Hukum

\footnotetext{
${ }^{7}$ Muhammad Sholikhin, Ritual Kematian Islam Jawa (Yogyakarta: Narasi, 2010), 165 .

${ }^{8}$ Ibid., 155.

${ }^{9}$ Koentjaraningrat, Kebudayaan Jawa, 124.

${ }^{10}$ Tebba, Sosiologi Hukum Islam, 1.
} 
dapat mempengaruhi perubahan masyarakat, dan sebaliknya perubahan masyarakat dapat mempengaruhi perubahan hukum.

Sama halnya jika dikaitkan dengan kajian hukum islam. Kajian sosiologi hukum islam dapat dilihat dari pengaruh hukum islam tersebut terhadap suatu masyarakat muslim, begitupun berlaku sebaliknya. Sosiologi hukum islam merupakan kajian atas proses terbentuknya Hukum islam yang menurut J.A William disebut juga dengan nama Fiqh (awalnya berartikan kebiasaan). ${ }^{11}$ Kemudian juga disebut dengan syariah. Kata fiqih yang dikaitkan dengan sosiologi hukum islam menunjukkan sebuat totalitas yang luas lingkunya dalam kehidupan, sehingga penerapannya dalam segala aspek kehidupan dianggap sebagai usaha memahami agama tersebut.

Namun sebenarnya, nama-nama dari hukum islam masih tumpang tindih. Menurut Roibin, dalam bukunya yang berjudul Sosiologi Hukum Islam-Telaah historis pemikiran imam syafi'i, ungkapan yang mewakili istilah hukum dalam Islam hingga kini tidak ditemukan istilah yang baku. Hal ini disebabkan oleh perbedaan keilmuan antara individu dalam memahami dimensi ontologis, Epistimologis, maupun aksiologis. ${ }^{12}$ Meski begitu perbedaan diasetiap istilah lain hukum islam tidak mempengaruhi makna dari proses dinamisasi semangat hukum yang pesat, yang mengakibatkan masingmasing istilah tersebut memiliki landasan paradigmatik lingkup kajian yang berbeda. ${ }^{13}$

Pembahasan ini berlanjut pada dasar pemikiran masing-masing individu. Ada yang berpikiran bahwa islam itu kaku, ada juga yang berpikiran bahwa islam merupakan agama yang memiliki hukum yang fleksibel, lentur, kompromistik serta adaptif terhadap sosio-kultural yang ada. Hal ini dibuktikan kepada salah satu dalil yang mengatakan bahwa islam itu agama yang tidak menyusahkan pemeluknya. “...inna ad-dinna yusrā..." (HR. Bukhori no.39) ${ }^{14}$

Hukum Allah dalam pembahasan ini mengacu pada Fiqh yaitu hasil oemahan subjektif individualistik yang tercipta dari para pakar ilmu dengan lingkungan sosio-kultural masing masing. Contohnya 4

\footnotetext{
11 Ibid., 1.

${ }^{12}$ Roibin, Sosiologi Hukum Islam (Telaah Sosio-Historis Pemikiran Imam Syafi'i (Malang: UIN Malang Press, 2008), 5.

13 Ibid., 20.

${ }^{14}$ Fazlur Rahman, Al-Islam (Bandung: Pustaka Pelajar, 1984), 140.
} 
Imam Mazhab. Mereka menciptakan fiqh berdasarkan sosio-kultural masing-masing dan kebutuhan masing-masing masyarakat di sekitarnya. Memang ada yang mengaplikasikan hukum tersebut berdasarkan kehati-hatian, tetapi tetap saja segala bentuk fiqh yang diciptakan tidak lepas dari sosio-kultural masing-masing imam mazhab tersebut. ${ }^{15}$

Sesungguhnya pembentukan pola hidup masyarakat muslim dan pola hidup masyarakat non muslim sangatlah berbeda. Hal ini terbukti pada pola hidup masyarakat non muslim yang berlandaskan pengalamam dan pemikiran sosial secara evolusi. Contohnya pola pemikiran darimana terciptanya manusia yang digambarkan dari teori Darwin. Berdasarkan ilmu secara rasional yang dimilikinya, Darwin menyebutkan bahwa Manusia berasal dari Bangsa Monyet. Hal itu ditepis oleh masyarakat muslim yang pola pemikiran serta hidup masyarakat muslim yang berlandaskan wahyu dari tuhan dan terbentuk secara revolusi. Masyarakat muslim mempercayai akan adanya nabi Adam sebagai manusia pertama yang diturunkan Allah SWT dari surga menjadi bakal adanya manusia dibumi ini.

Selanjutnya pola hidup masyarakat Yunani akan kewajiban mengorbankan seorang perempuan muda kepada dewa sebagai tolak bala. Hal ini berkaitan dengan dasar pengalaman dari masyarakat terdahulu yang berfikiran bahwa perempuan muda tersebut kelak akan menjadi penglipur lara dewa dalam menyelesaikan segala tugasnya untuk memelihara manusia dibumi. Hingga akhirnya masalah yang dibumi terselesaikan tanpa adanya hambatan.

Berbeda dengan pola hidup masyarakat muslim yang melakukan pengorbanan hewan saat idul adha. Masyarakat muslim tidak hanya melakukan pengorbanan ini berdasarkan tinjauan Sosiologis tetap melestarikan kebiasaan arab jahiliyah yang melakukan korban bagi dewa mereka. Dengan berubahnya agama mereka menjadi islam maka tujuan dari pengorbanan tersebut berdasarkan kitab suci agama mereka yang datang melalui Wahyu Allah SWT kepada Nabi Muhammad SAW yaitu demi meghormati pengorbanan nabi, yang rela mengorbankan anaknya untuk Allah SWT, serta mensyukuri rahmat karunia dari tuhan Allah SWT dan kemudian diganti oleh Allah SWT dengan Hewan ternak.

${ }^{15}$ Tebba, Sosiologi Hukum Islam, 5. 
Perbedaan dari masalah diatas terlihat dari jenis korbannya, Masyarakat non muslim menggunakan manusia yang jelas menyalahi Hak Asasi Manusia untuk tinjauan hukum saat ini dan akhirnya tidak dilakukan kembali. sedangkan Masyarakat muslim menggunakan hewan yang hingga saat ini tetap dilanjutkan. Kasus ini menunjukkan bahwa hukum islam itu dapat mempengaruhi bahkan mengubah suatu sistem sosial yang telah mapan contohnya sistem sosial arab jahiliyah. $^{16}$

Dari sini terlihat bahwa fiqih tidak hanya berfungsi sebagai hukum sekuler melainkan berfungsi sebagai nilai normatif yang menjadi satu-satunya pranata kehidupan sosial dalam islam yang dapat memberikan legitimasi terhadap perubahan-perubahan yang dikehendaki dalam penyelarasan ajaran agama dengan dinamika sosial yang terjadi. ${ }^{17}$

Di Indonesia, Khususnya daerah Jawa terdapat kelompok Kejawen. Kejawen adalah sebuah kepercayaan atau mungkin boleh dikatakan agama, yang terutama yang dianut di pulau jawa dan suku bangsa lainnya yang menetap di Jawa.Kejawen sebenarnya adalah nama sebuah kelompok kepercayaan-kepercayaan yang mirip satu sama lain dan bukan sebuah agama yang terorganisir seperti agama Islam atau agama Kristen. ${ }^{18}$

Ciri khas dari Kejawen adalah adanya perpaduan antara animisme, agama Hindu dan agama Budha. Nampak bahwa ini adalah sebuah kepercayaan sinkretisme. Pengamatan Geetz tentang Mojokuto terkait profesi penduduk setempat. Penggolongan penduduk menurut pandangan masyarakat Mojokuto berdasarkan kepercayaan, profesi, etnis dan pandangan politik dan di temukannya tiga inti struktur sosial yakni desa, pasar dan birokrasi pemerintah yang mencerminkan tiga tipe kebudayaan abangan, santri dan priyayi.

Masyarakat kejawen khususnya islam kejawen terdapat tradisi ritual yang sederhana, formal, jauh dari keramaian serta apa adanya, Ritual adalah suatu teknik atau cara yang membuat suatu adat kebiasaan menjadi suci (sanctify the custom). Ritual menciptakan dan memelihara mitos, adat sosial, dan agama. Ritual bisa bersifat pribadi

\footnotetext{
${ }^{16}$ Ibid., 5.

17 Ibid., 1.

${ }^{18}$ khalil, Islam Jawa, (Sufisme dalam etika dan Tradisi Jawa), 277.
} 
ataupun berkelompok. Wujudnya bisa berupa tarian, drama, doa, dan sebagainya. Sebut saja "Slametan". ${ }^{19}$ Slametan berasal dari kata slamet (Arab: salamah) yang berarti selamat, bahagia, sentausa. Selamat dapat dimaknai sebagai keadaan lepas dari insiden-insiden yang tidak dikehendaki. Sementara itu, Clifford Geertz slamet berarti ora ana apa-apa (tidak ada apa-apa) selamatan adalah suatu bentuk acara syukuran dengan mengundang beberapa kerabat atau tetangga. Secara tradisional acara syukuran dimulai dengan doa bersama, dengan duduk bersila di atas tikar, melingkari nasi tumpeng dengan lauk pauk. ${ }^{20}$

Praktik upacara selamatan sebagaimana yang diungkapkan oleh Hildred Geertz tersebut pada umumnya dianut oleh kaum Islam Abangan, sedangkan bagi kaum Islam Putihan (santri) praktik selamatan tersebut tidak sepenuhnya dapat diterima, kecuali dengan membuang unsur-unsur syirik yang menyolok seperti sebutan dewadewa dan roh-roh. Karena itu bagi kaum santri, selamatan adalah upacara doa bersama dengan seorang pemimpin atau modin yang kemudian diteruskan dengan makan-makan bersama sekadarnya dengan tujuan untuk mendapatkan keselamatan dan perlindungan dari Allah Yang maha Kuasa. ${ }^{21}$

Slametan dilakukan untuk merayakan hampir semua kejadian, termasuk kelahiran, kematian pernikahan, pindah rumah, dan sebagainya. Dalam Pembahasan kali ini, penulis terfokus pada salah satu tradisi yang sudah mengakar kuat ribuan tahun lamanya di Indonesia, terutama di Tanah Jawah, adalah tradisi "slametan" bagi orang yang sudah meninggal dunia. ${ }^{22}$

Sebelum Islam masuk ke Indonesia, slametan identik dengan sesajen yang di persembahkan untuk roh-roh halus. Setelah Islam masuk ke bumi Nusantara, para penyebar Islam berupaya menyisipkan nilai-nilai Islam di dalamnya. Mereka berusaha merubah tradisi slametan bukan lagi sebagai persembahan untuk makhluk halus, melainkan sebagai sedekah yang tidak hanya merekatkan hubungan antara masyarakat, akan tetapi juga melatih kepedulian sosial. ${ }^{23}$
19 Ibid., 277.
${ }^{20}$ Ibid., 278.
21 Ibid., 279.
${ }^{22}$ Koentjaraningrat, Kebudayaan Jawa, 124.
23 Ibid., 125. 


\section{Mitos Ritual Kematian Islam Kejawen}

Upacara slametan yang sama diselenggarakan pada saat kematian itu mencapai tujuh hari (mitungdina), 40 hari (matang puluh), 100 hari (nyatus), satu tahun (mendhak sepisan), dua tahun (mendhakpindho) dan tiga tahun (nyewu). ${ }^{24}$ Tahlilan kirim do'a kepada leluhur terkadang dilakukan juga oleh keluarga secara bersamasama pada saat ziarah kubur, khususnya pada waktu menjelang ramadhan. Menurut tradisi eskatologi yang bersumber pada ajaran sufi (Syattariyah), praktek selamatan peringatan dihubungkan dengan proses pembusukan tubuh yang mati sebelum pada akhirnya melebur seluruhnya dengan tanah. Dalam kondisi normal, proses ini berlangsung pada tujuh tahap. ${ }^{25}$

Tahap pertama adalah tiga hari setelah pemakaman, ketika jasad diyakini membengkak. Tahap kedua, adalah hari ketujuh, ketika pembengkakan mencapai puncaknya dan meletus. Setelah itu daging terurai dan mulai membusuk. Tahap ketiga, Setelah 40 hari, proses pembusukan ini diikuti dengan pergerakan tubuh secara perlahan tapi pasti. Kepala menjadi tegak, seperti halnya lutut, Tahap keempat, pada hari ke 100, tubuh yang membusuk berubah dari posisi tidur keposisi berdiri. Proses ini berlangsung hingga kaki melenting kebelakang dan kepala kedepan. Tahap kelima, Setahun kemudian, kepalaakan mencapai lutut.

Tahap keenam, Di tahun kedua ketika semua daging sudah tidak tersisa, lkaki jenazah akan tertekuk hingga kebawah pantat, sedangkan kepala akan mencapai lutut. Akhirnya, Tahap ketujuh, dalam waktu tiga tahun atau 1000 hari semua tulang akan terkumpul bersama sebelum akhirnya melebur dengan tanah. Gerakan tulang ini didalam proses pembusukan, khususnyagerakan kepala, diyakini mengikuti, dengan arah terbalik, proses pertumbuhan bayi saat berada didalam kandungan (yang juga berlangsung dalam tujuh tahap).

Menurut ajaran sufi Syattariyahini, proses pelarutan tersebut memilik iartimistis. Masing-masing tahap layak dicermati dan inilah alasan mengapa slametan perlu diadakan. Tradisi ini terjadi dari keinginan untuk menghibur pada keluarga yang ditinggalkan sekaligus

\footnotetext{
${ }^{24}$ khalil, Islam Jawa, (Sufisme dalam etika dan Tradisi Jawa), 280.

${ }^{25}$ Muhammad Sholikhin, Ritual Kematian Islam Jawa, 159-60.
} 
mengambi liktibar bahwa yang masih hidup juga akan segera menyusul (mati) dikemudian hari.Aktifitas tahlil/zikir yang berawal dari ajaran tarekat itulah yang kemudian meluas menjadi tradisi tahlilan. ${ }^{26}$ Dikatakan sebagai tahlil, karena memang dalam pelaksanaanya lebih banyak membaca kalimat-kalimat tahlil yang mengesakan Allah seperti 'tahlil' (membaca lailahaillallah), tahmid, dan lain sebagainya sesuai dengan tradisi masyarakat setempat atau pemahaman dari guru (syekh) suatu daerah tertentu. Kehadiran instrument islam akan selalu mengakibatkan transformasi sosial (Sosial Transformation) menuju suatu bentuk baru yang tidak serta merta memotong habis masa lampau budaya lokal yang dimasukinya, melainkan dapat juga melestarikan apa saja yang baik dan benar dari masa lampau. Tradisi tahlilan tidak hanya dikenal dikalangan umat Islam di Indonesia. Menurut Agus Sunyoto-penulis buku Syekh Siti Jenar-berpendapat bahwa tahlil juga dilaksanakan di Iran, Hal tersebut didasarkan pada kenyataan bahwa ketika Imam Khomeini- pemimpin Syi'ah-meninggal juga diadakan tahlil untuk mendoakanya. ${ }^{27}$

Menurut Sosiologi Hukum islam, sejak Islam pertama kali hadir di Indonesia, saat ada orang meninggal dunia bisanya para tetangga dan kerabat berkumpul untuk menyampaikan rasa duka cita. Tapi kemudian, pada malam harinya mereka main kartu, mabukmabukan, dan lain-lain. Budaya seperti ini membuat prihatin para ulama, sehingga sedikit demi sedikit mereka berupaya merubahnya. Mereka memasukkan budaya-budaya Islami ke dalam tradisi warisan Hindu ini, seperti membaca al-Qur'an, tahlil, tahmid, tasbih, yang hingga kini dikenal dengan istilah "tahlilan". Setelah tahlilan, tuan rumah biasanya menyajikan makanan dan minuman ala kadarnya, bahkan tak jarang ditambah dengan bungkusan "berkat" untuk dibawa pulang. Semua itu dilakukan sebagai sedekah yang pahalanya dihadiahkan kepada si mayit. ${ }^{28}$

Dari sini dapat kita pahami, bahwa tradisi slametan pada masa sekarang sudah berbeda jauh dengan slametan pada zaman dahulu. Walaupun kini sudah "Islami", akan tetapi sebagian umat Islam masih menolak tradisi tahlil. Mereka menganggapnya sebagai bid'ah yang haram. Sebab: Tradisi tahlilan tidak pernah disyariatkat oleh Allah dan

\footnotetext{
${ }^{26}$ Ibid., 162.

27 Ibid., 163.

${ }^{28}$ Ibid., 163.
} 
tidak pernah dilakukan oleh Nabi Muhammad SAW dan sahabatnya. Tradisi ini merupakan transfer pahala dari orang yang masih hidup kepada yang sudah mati, dan itu bertentangan dengan ajaran Islam. Tradisi ini akan membuat orang mudah berbuat dosa, karena dia berkeyakinan bahwa dosanya bisa ditebus dengan tahlilan dan dzikir fida'. Hal itu mudah dilakukan oleh orang-orang kaya. Tradisi ini merupakan tindak pemborosan, karena memberikan sedekah kepada orang-orang yang tidak membutuhkan (bukan fakir miskin).

Pendapat ini seirama dengan pandangan Ibnu Hajar al-Haitami. Dalam al-Fatawi al-Kubra, Ibnu Hajar berpendapat bahwa peringatan hari ketiga, ketujuh, dan lain-lain yang telah membudaya di masyarakat, termasuk bid'ah madzmumah (bid'ah tercela), akan tetapi tidak diharamkan, selama bukan untuk meratapi kematian si mayit. ${ }^{29}$

Sementara kalangan yang mendukung tradisi tahlilan menilai, bahwa tradisi ini sama saja dengan ajaran membacakan ayat suci alQur'an untuk orang mati, dimana hal itu merupakan anjuran Islam. Selain itu, tradisi tahlilan juga mengandung sisi positif, antara lain: ${ }^{30}$

1. Menumbuhkan semangat dakwah dan kebersamaan, serta menjadi sarana untuk mendekatkan diri kepada Allah SWT. Dengan cara berdzikir bersama mendoakan si mayit.

2. Untuk mengingatkan kita bahwa akhir kehidupan adalah kematian.

3. Untuk menanamkan jiwa kepedulian sosial terhadap sesama, walaupun hanya dengan cara mendoakan si mati. Dan telah kita maklumi, salah satu upaya menebus kesalahan kepada orang lain (terutama yang telah wafat) adalah dengan mendoakannya.

Jika diteliti lebih jauh, tradisi tahlilan sebenarnya tidak didasarkan pada dalil khusus yang menganjurkan maupun melarangnya. Dalam al-Qur'an dan hadits tidak ada dalil yang memerintahkan maupun melarang umat Islam me-nahlili kerabatnya yang sudah meninggal. Akan tetapi, karena esensi tahlil adalah untuk menumbuhkan semangat dakwah, membangunkebersamaan, mendekatkan diri kepada Allah SWT. Melalui dzikir, doa, dan lainlain, serta untuk mendoakan si mati dan mengingatkan kepada kematian, maka tradisi tahlilan sebenarnya mempunyai nilai positif.

\footnotetext{
${ }^{29}$ Ibid., 165.

${ }^{30}$ Ibid., 155.
} 
Yang perlu di ingat, jangan sampai tahlilan itu memberatkan keluarga si mati, karena Islam justru menganjurkan umatnya untuk meringankan beban mereka. Disamping itu, pihak keluarga jangan beranggapan bahwa tahlil adalah kewajiban syariat.

Syaikh al-Nawawi al-Bantani dalam Nihayat al-Zain menyatakan, bersedekah untuk si mati sangat dianjurkan, dengan catatan tidak bertentangan dengan aturan syariat. Akan tetapi, anjuran itu tidak khusus hanya pada hari ketujuh, keempat puluh, keseratus, dll. Bersedekah pada hari-hari yang lain juga boleh. ${ }^{31}$ Sebenarnya ritual ini pertamanya bersifat sosial kemudian bersifat ekonomis lalu berkembang menjadi tata cara suci agama.

Jika tujuan tahlil adalah untuk bersedekah dan berdoa bagi si mati, maka ritual ini tidak bertentangan dengan al-Qur'an dan hadits. Hal ini diperkuat dengan hadits Nabi riwayat Abu Dawud: "Bacalah Surat Yaasin pada orang yang mati di antara kalian". Muhammad Ibn Ahmad al-Maruzi mendengar Ahmad bin Hanbal berkata, "Ketika kalian memasuki area kuburan, maka bacalah surat al-Fatihah, alIkhlas, dan al-Mu'awidatain (al-Falaq dan al-Nas). Dan jadikanlah pahala bacaan itu untuk penghuni kubur, maka pahala tersebut akan sampai kepadanya". ${ }^{32}$ Dari sini dapat diketahui bahwa bacaan-bacaan tersebut sebenarnya merupakan esensi dari tahlil itu sendiri. ${ }^{33}$

Suatu ciri khas masyarakat dalam menghadapi keluarga yang berduka cita adalah bertakziyah dengan membawa bawaan untuk diberikan kepada keluarga si mayat, dengan harapan dapat membantu meringankan penderitaan mereka selama waktu berduka cita. Bentuk bawaan menurut kebiasaan dapat berupa beras, gula, uang dan lain sebagainya. Tradisi nyumbang merupakan wujud solidaritas seorang anggota masyarakat terhadap saudara, anggota, rekan kerja atau anggota masyarakat lainnya yang sedang memiliki hajatan.

Menurut Malinowsky dalam kutipan Koentjaraningrat sistem menyumbang untuk menimbulkan kewajiban membalas merupakan suatu prinsip dari kehidupan masyarakat kecil yang disebut "principle ofreciprocity" (prinsip timbal balik). ${ }^{34}$ Maksudnya, orang memberi sumbangan dan membantu sesamanya tidak selalu dengan rela atau

\footnotetext{
31 Ibid., 152.

${ }^{32}$ Ibid., 155.

${ }^{33}$ Ibid., 162.

${ }^{34}$ Ibid., 166.
} 
spontan karena terpaksa oleh suatu jasa yang pernah diberikan kepadanya dan ia menyumbang untuk mendapat pertolongan lagi di kemudian hari, malahan dalam berbagai hal orang desa sering memperhitungkan dengan tajam tiap jasa yang pernah disumbangkan kepada sesamanya itu dengan harapan bahwa jasa-jasanya akan dikembalikan dengan tepat pula. Tetapi dalam tradisi selamatan kematian prinsip ini tidak ditemukan karena mereka menyumbang penuh dengan kerelaan dan keikhlasan. Dalam konteks sosiologis, ritual selamatan kematian sebagai alat memperkuat solidaritas sosial, maksudnya alat untuk memperkuat keseimbangan masyarakat yakni menciptakan situasi rukun, toleransi di kalangan partisipan, serta juga tolong-menolong bergantian untuk memberikan berkah (do'a) yang akan ditujukan pada keluarga yang sudah meninggal.

Akulturasi adalah suatu proses sosial yang timbul mana kala ada sebuah kebudayaan asing yang masuk dan kebudayaan itu diterima serta diolah oleh suatu kelompok masyarakat tanpa menghilangkan ciri khas kebudayaan masyarakat itu sendiri. ${ }^{35}$ Akulturasi merupakan sebuah istilah dalam ilmu sosiologi yang berarti pengambilalihan unsur-unsur kebudayaan lain. ${ }^{36}$ Akulturasi terjadi karena adanya keterbukaan suatu masyarakat. Selain itu "perkawinan" dua kebudayaan bisa terjadi karena pemaksaan dari kebudayaan asing yang memasukkan unsur kebudayaan mereka. Selain kedua hal itu, akulturasi dapat juga terjaadi karena beberapa hal, antara lain; kontak dengan budaya lain, sistem pendidikan yang maju yang mengajarkan seseorang untuk lebih berfikir ilmiah dan objektif, keinginan untuk maju, sikap mudah menerima hal-hal baru dan toleransi terhadap perubahan. Contoh akulturasi budaya adalah bangunan masjid Kudus merupakan hasil akulturasi antar Islam dan Hindu, serta perwayangan di daerah jawa dan sekitarnya yang mengangkat cerita Ramayana dan Mahabarata merupakan wujud akulturasi kebudayaan antara HinduBudha di bidang kesenian.

Maksudnya agama tersebut harus menyesuaikan diri dengan beberapa aspek lokal sekiranya tidak bertentangan dengan dengan kehadiran islam di jawa. Umumnya, para pendakwah islam dapat menyikapi tradisi lokal yang di padukan menjadi bagian tradisi yang "Islami" karena berpegangteguh dengan kaidah ushuliyah (kaidah

\footnotetext{
${ }^{35}$ khalil, Islam Jawa, (Sufisme dalam etika dan Tradisi Jawa), 282.

${ }^{36}$ Tebba, Sosiologi Hukum Islam, 8.
} 
yang menjadi pertimbangan yang merumuskan hukum fiqih). Sebagaimana kaidah yang berbunyi: المحافظة القديم الصالح,والاحظ الجديد الاصل (Menjaga nilai - nilai lama yang baik, sembari mengambil nilai - nilai baru yang lebih baik) ${ }^{37}$

Masuknya Islam keJawa memberikan warna baru pada upacara-upacara dalam tradisi Jawa, termasuk upacara kematian. Menurut keyakinan Islam, orang-orang yang sudah meninggal dunia ruhnya tetap hidup sebagaimana menurut orang Jawa, hanya saja ruh itu tinggal sementara di alam kubur atau alam barzah, yakni alam sebelum memasuki alam akhirat. Dari sini dapat dilihat bahwa baik dalam kepercayaan Islam maupun Jawa mempunyai pandangan yang hampir sama, akan tetapi terkait dengan kepercayaan orang jawa yang memandang bahwa roh-roh atau dhanyang-dhanyang itu menjaga dan mengawasi seluruh masyarakat desa serta memberikan perlindungan sehingga perlu diadakan upacara pemujaan dan pemberian sesaji Islam tidak sepakat, karena menurut Islam, yang memberikan perlindungan hanya Allah dan ritual-ritual yang diadakan untuk pemujaan kepada roh-roh halus sama saja dengan menyekutukan Tuhan (Allah), sehingga Islam melarang ritual-ritual sesaji. ${ }^{38}$

Akan tetapi disisi lain, Islam percaya bahwa orang yang meninggal dunia perlu dikirimi doa. Maka, atas dasar inilah kemudian ajaran Islam dapat masuk kedalam kepercayaan orang Jawa dengan merubah pandangan mereka bahwa orang yang meninggal dunia tidak perlu dipuja dan diberi sesajian, tetapi perlu dikirimi do'a agar menjadi tambahan bekalnya di alam kubur. Sedangkan bentuk pemberian sesaji dirubah dengan bentuk pemberian shadaqah atau yang biasadisebut orang Jawa dengan istilah berkat. Dari sinilah Islam dapat berinterelasi dengan mudah kedalam kepercayaan tradisi Jawa.

Secara luwes, Islam memberikan warna baru pada upacaraupacara itu dengan sebutan kenduren atau selametan. Tradisi selamatan yang inti pokoknya adalah pembacaan do'a untuk yang meninggal dunia ini sendiri untuk penentuan hari pelaksanaannya disesuaikan dengan warisan budaya sebelum Islam, yakni seperti hari-hari

\footnotetext{
${ }^{37}$ Muhammad Sholikhin, Ritual Kematian Islam Jawa, 152.

${ }^{38}$ khalil, Islam Jawa, (Sufisme dalam etika dan Tradisi Jawa), 289.
} 
pemujaan yang biasa dilakukan orang-orang Jawa sebelum datangnya Islam. ${ }^{39}$

\section{Kesimpulan}

Kejawen adalah sebuah corak kepercayaan yang dianut di pulau jawa dan suku bangsa lainnya yang menetap di Jawa. Ciri khas dari Kejawen adalah adanya perpaduan antara animisme, agama Hindu dan agama Budha. Nampak bahwa ini adalah sebuah kepercayaan sinkretisme. Masyarakat kejawen khususnya islam kejawen terdapat tradisi ritual yang sederhana, formal, jauh dari keramaian serta apa adanya, Slametan dilakukan untuk merayakan hampir semua kejadian, termasuk kelahiran, kematian pernikahan, dan pindah rumah, dari papran dapat disimpulkan bahwa tradisi slametan pada masa sekarang sudah berbeda jauh dengan slametan pada zaman dahulu. Secara luwes, Islam memberikan warna baru pada upacara-upacara dengan sebutan selametan. Tradisi selamatan yang inti pokoknya adalah pembacaan do'a untuk yang meninggal dunia ini sendiri untuk penentuan hari pelaksanaannya disesuaikan dengan warisan budaya sebelum Islam, yakni seperti hari-hari pemujaan yang biasa dilakukan orang-orang Jawa sebelum datangnya Islam. [.]

${ }^{39}$ Muhammad Sholikhin, Ritual Kematian Islam Jawa, 174. 
Nurul Mahmudah \& Abdur Rahman Adi Saputra

\section{Referensi}

Fauzan. "Akulturasi Islam dan Budaya Jawa: Kajian Pada Ritual 'Pengesahan' Warga Baru Persaudaraan Setia Hati Terate." Kalam Vol. 6, no. 1 (2012): 105-24.

khalil, Ahmad. Islam Jawa, (Sufisme dalam etika dan Tradisi Jawa). Malang: UIN Malang Press, 2008.

Koentjaraningrat. Kebudayaan Jawa. Jakarta: Balai Pustaka, 1984.

Muhammad Sholikhin. Ritual Kematian Islam Jawa. Yogyakarta: Narasi, 2010.

Rahman, Fazlur. Al-Islam. Bandung: Pustaka Pelajar, 1984.

Roibin. Sosiologi Hukum Islam (Telaah Sosio-Historis Pemikiran Imam Syafi 'i. Malang: UIN Malang Press, 2008.

Tebba, Sudirman. Sosiologi Hukum Islam. Yogyakarta: UII Press, 2003. 